\title{
Caminhos cruzados: relação entre empresa, trabalhadores e sindicato em Polo oleiro-cerâmico da Região Metropolitana de Manaus-AM
}

\section{Crossroads: the relationship among company, workers and trade union at the Pole potter-ceramic of Metropolitan Region of Manaus-AM}

Cleiton Ferreira Maciel - Programa de Pós-Graduação em Sociologia da Universidade Federal de São Carlos; bolsista da Fundação de Amparo à Pesquisa do Estado do Amazonas (FAPEAM), Manaus-AM. E-mail: cleiton.keto@hotmail.com

Maria Izabel de Medeiros Valle - Programa de Pós-Graduação em Sociologia da Universidade Federal do Amazonas, Manaus-AM. E-mail: izabel.valle@ufam.edu.br

Jeanne Mariel Brito de Moura - Programa de Pós-Graduação em Sociologia da Universidade Federal de São Carlos. Sociologia Rural. E-mail: maribrito21@yahoo.com.br

\section{Resumo}

O presente artigo é fruto da pesquisa do mestrado em Sociologia na Universidade do Amazonas, de 2011 a 2013, e analisa a relação entre empresa, trabalhadores e sindicatos no Polo oleiro-cerâmico da Região Metropolitana de Manaus, setor que fabrica $75 \%$ dos tijolos e telhas consumidos no Amazonas. A ideia central deste trabalho é mostrar quais são as principais estratégias empresariais empreendidas pelo dono da olaria investigada, bem como traçar um perfil dos trabalhadores oleiros. Além disso, busca-se revelar o papel do sindicato oleiro na luta por melhorias nas condições de trabalho e aumento de salários. Dentre os resultados da pesquisa, destacam-se: as precárias condições de trabalho às quais os trabalhadores da olaria estão submetidos; os baixos salários; a ausência da participação sindical; e a busca pelo controle da mão de obra.

\section{Palavras-chave}

Olaria. Sindicato. Estratégias empresariais. Controle do trabalho. Região Metropolitana de Manaus.

\begin{abstract}
This article is the result of research masters degree in Sociology at the University of Amazonas year from 2011 to 2013, and analyzes the relationship between the company, employees and trade unions in Pole potter-ceramic of Metropolitan Region of Manaus, a sector that produces $75 \%$ of the bricks and tiles consumed in the Amazon. The central idea of this work is to show what are the key business strategies undertaken by the owner of the pottery investigated, as well as to profile potters workers. In addition, it seeks to reveal the role of the potter trade union in the battle for improvements in working conditions and higher wages. Among the results of the research are: the precarious jobs which potter workers are subjected; low wages; the absence of trade union involvement; and the quest for control of the hand labor.
\end{abstract}

\section{Keywords}

Pottery. Trade union. Business strategies. Control of work. Metropolitan Region of Manaus. 


\section{INTRODUÇÃO}

A produção de cerâmica vermelha (tijolos e telhas) é uma atividade importante para a economia do Brasil, respondendo por cerca de $1 \%$ do PIB nacional, dentro de um mercado que fechou o ano de 2012 com crescimento de $11 \%$ (ANICER, 2012). Trata-se de uma atividade produtiva com aproximadamente 6.903 cerâmicas espalhadas pelo Brasil, e que produz anualmente cerca de 5 bilhões de peças. Em termos da mão de obra, o setor gera 293 mil empregos diretos e 900 mil indiretos, com um faturamento que chegou a $\mathrm{R} \$ 18$ bilhões em 2011. Diante da existência de um mercado consumidor que por razões históricas ${ }^{1}$ é o maior do Brasil, a concentração nacional das indústrias ceramistas está localizada na região sudeste (ANICER, 2012).

Face a essa configuração da indústria ceramista nacional, a região Norte emerge como um importante ator dentro desse cenário de fabricação de tijolos e telhas, tendo uma participação considerável na produção mensal, a qual está estimada em 114 milhões de peças e que gera, segundo dados do SEBRAE, cerca de 10 mil empregos diretos e indiretos (SEBRAE, 2011).

No que diz respeito ao estado do Amazonas, a produção de cerâmica vermelha está concentrada nos municípios de Manacapuru e Iranduba ${ }^{2}$. Entretanto, este último tradicionalmente se apresenta como o principal polo oleiro-cerâmico do estado, com um total de 25 olarias instaladas e associadas à ACERAM ${ }^{3}$. Segundo Trindade (1999), esta concentração deve-se à relação de proximidade que o município tem em relação à capital amazonense ${ }^{4}$. Acrescen-se a isso, segundo o autor, a grande disponibilidade de argila de alta qualidade, que é a principal matéria-prima desse ramo de atividade econômica. Outro fator que contribuiu para que Iranduba se tornasse o maior produtor de cerâmica vermelha do Amazonas, foi o não pagamento de $\mathrm{ICMS}^{5}$ quando do ingresso do produto na cidade de Manaus, principal mercado consumidor da produção oleira amazonense.

\footnotetext{
Referimos-nos aqui a dois pontos: a concentração populacional no Sudeste do Brasil e a consequente urbanização dessa região, contrastando com o Norte do Brasil, por exemplo, que teve um processo de urbanização e de crescimento populacional tardio.

2 Esses dois municípios fazem parte da Região Metropolitana de Manaus (RMM). Criada em 30 de maio de 2007, a RMM teve seu elemento embrionário forjado na premissa de que era preciso aproximar de Manaus os municípios que estavam em seu entorno, distribuindo melhor os recursos provindos do modelo Zona Franca. Assim, oito municípios passaram a fazer parte desse processo de metropolização regional: Manaus, Careiro da Várzea, Iranduba, Manacapuru, Itacoatiara, Presidente Figueiredo, Novo Airão e Rio Preto da Eva, com uma população total de 2.175.860 habitantes, e que registra um PIB de $\mathrm{R} \$ 36$ bilhões.

Associação dos Ceramistas do Estado do Amazonas.

A cidade de Iranduba fica distante $20 \mathrm{~km}$ de Manaus, fazendo parte da sua Região Metropolitana. Imposto sobre Circulação de Mercadorias e Serviços.
}

Novos Cadernos NAEA, v. 16, n. 1, Suplemento, p. 127-162, nov. 2013 


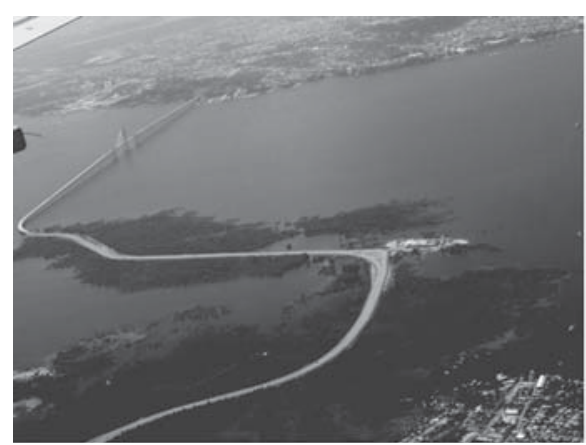

Figura 1. Vila do Cacau Pirêra (abaixo), distrito da cidade de Iranduba. O transporte de tijolos e telhas era feito até Manaus (acima) pelo porto dessa vila, antes da construção da ponte Rio Negro. Foto do autor, 2011.

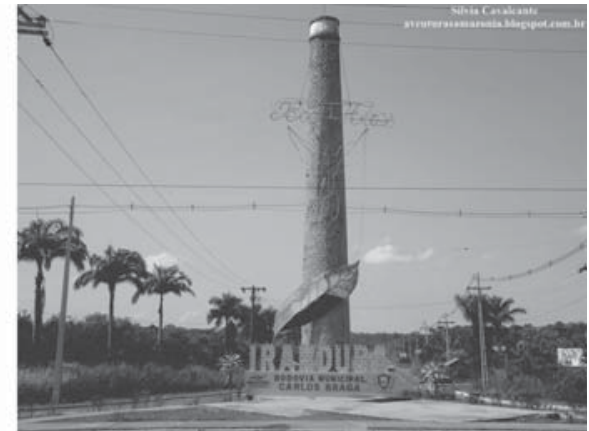

Figura 2. Portal da cidade de Iranduba, onde é possível ver o símbolo da cidade: uma chaminé oleira. Foto da internet, s/d.

A primeira fábrica de tijolos do município de Iranduba data de 1946, época em que a cidade ainda era distrito de Manaus, tendo sido pioneira a Cerâmica Marajó, que ainda hoje opera na fabricação desse tipo de produto. Em 10 de dezembro de 1981, a Vila de Iranduba tornou-se um município autônomo, sendo elevada à categoria de cidade, com o mesmo nome (CHAVES, 2001).

Em um primeiro momento, o município teve sua base econômica centrada no setor primário, como o cultivo de hortaliças, criação de bovinos de corte e de leite e cultivo de frutos (ABREU, 2004). Contudo, com a expansão imobiliária ocorrida em meados dos anos 1980, por conta do estímulo dado à construção civil através do Sistema Financeiro de Habitação, ocorreu uma explosão na demanda por produtos da indústria oleira-cerâmica, fazendo com que os empresários de Manaus passassem a vislumbrar uma oportunidade de obter lucros no emergente mercado imobiliário, e iniciassem um processo de investimento na aquisição de terrenos e máquinas para a instalação de novas indústrias ceramistas no município de Iranduba (TRINDADE, 1999).

Hoje, o município de Iranduba é responsável por cerca de 75\% de toda a produção de cerâmica vermelha do estado do Amazonas, o que representa, em termos quantitativos, 35 toneladas de tijolos por mês (SEBRAE, 2011). Além disso, o Polo Oleiro-Cerâmico de Iranduba movimenta, em média, 80\% da construção civil amazonense, gerando, cerca de 2.000 empregos diretos e indiretos no município, abrangendo um total de 6.000 trabalhadores, entre prestadores de serviço e fornecedores (ACERAM, 2012). 


\section{AS OLARIAS DE IRANDUBA: CRISE E TRANSFORMAÇÕES NA ESTRUTURA PRODUTIVA}

Desde meados da década de 1990, o setor oleiro de Iranduba vinha enfrentando desde meados problemas na sua estrutura produtiva, o que impedia uma maior produtividade das empresas ali instaladas. Segundo Trindade (1999), essas empresas oleiras tinham uma excessiva concentração da oferta em um único produto ${ }^{6}$, fato este que acirrava a concorrência e afetava a lucratividade do setor. Aliado a isto, existia a dificuldade de transporte de matéria-prima (argila) e lenha através das estradas vicinais não asfaltadas. Esses fatores engendraram o aumento do custo do transporte da argila, a impossibilidade de abastecimento de algumas olarias durante o período de chuvas (janeiro a maio) e a elevação no prazo de produção e entrega dos produtos.

Outro problema que o autor ressalta eram as multas aplicadas por órgãos governamentais, como o IBAMA e IPAAM ${ }^{7}$, por conta da legislação ambiental. A maioria das empresas comprava lenha dos pequenos produtores rurais, os quais não tinham permissão desses agentes para desmatar e transportar esse produto. A consequência dessas ações, segundo Trindade (1999), eram as paralisações por falta de lenha, a elevação dos custos de produção e o aumento no preço do milheiro de tijolo ${ }^{8}$.

A lenha nativa era a principal matéria-prima usada nos fornos de queima de tijolos, sendo que a maioria das empresas comprava esse material dos pequenos produtores rurais, os quais não tinham permissão dos órgãos ambientais para desmatar, transportar e vender a madeira às olarias. No início dos anos 2000 era comum ver caminhões com a carroceria cheias de "toras" de árvores semiqueimadas, uma vez que grande parte dessa lenha provinha dos roçados ${ }^{10}$ localizados nas proximidades do Polo oleiro-cerâmico ${ }^{11}$.

No entanto, em face da chamada "crise ambiental" que vem forjando a atual conjuntura mundial de leis de proteção ao meio ambiente, os órgãos ambientais como IBAMA e IPAAM passaram a realizar, sobretudo a partir de 2003, uma série de operações, tendo em vista a fiscalização contínua do transporte ilegal de lenha pelas estradas dessa região amazônica, bem como o acompanhamento por satélite das áreas desmatadas no entorno das olarias ${ }^{12}$.

\footnotetext{
Tijolos de oito furos.

Instituto Brasileiro do Meio Ambiente e Recursos Naturais Renováveis e Instituto de Proteção Ambiental do Amazonas, respectivamente.

Mil tijolos são vendidos, em média, por R \$380,00 em Iranduba.

Pedaços das árvores geralmente cortados com motoserra.

10 Área desmatada e queimada usada, para a plantação, sobretudo de mandioca.

11 No ano 2000 o índice de área desmatada em Iranduba era de 13,39\%, sendo que no mesmo período a média amazonense era de $2 \%$ (MACIEL; VALLE, 2010).

12 O Polo oleiro-cerâmico está situado a apenas 10 quilômetros do maior hotel de selva do Amazonas: o Ariaú Amazon Tower.
}

Novos Cadernos NAEA, v. 16, n. 1, Suplemento, p. 127-162, nov. 2013 
Tratava-se, assim, de um momento fulcral dentro da organização produtiva oleira-cerâmica, ou seja, buscava-se mudar a base de material de queima de tijolos, sinalizando às agências de proteção ambiental o interesse em se enquadrar na lógica do "desenvolvimento sustentável" ou se continuava a operar do modo "tradicional", constituindo-se, portanto, em empresas ilegais dentro de um cenário de pressão ambiental não apenas local, mas, principalmente, global.

No bojo dessas metamorfoses em curso na Amazônia, as olarias voltaramse à primeira plataforma de mudanças, qual seja, implementar uma agenda de alterações na configuração produtiva que, por um lado, desse conta de responder positiva e satisfatoriamente aos interesses dos órgãos ambientais nacionais e globais, e, por outro, fosse cômodo à reprodução dos interesses dos empresários do setor oleiro.

As condições propícias ao desenvolvimento de uma política organizacional que favorecesse aos diversos agentes foram forjadas através da ação do próprio estado, com base em um projeto de Arranjos Produtivos Locais, o qual, no caso do setor oleiro, teve o SEBRAE como a força transformadora da engrenagem que se tinha até aquele momento. O que haveria de ser realizado se constituiria, assim, não em uma ruptura com as práticas produtivas do passado, mas em uma fase de transição cômoda rumo a um modelo "moderno" de organização industrial, em que os diversos interesses e forças em jogo teriam suas demandas atendidas, ainda que em níveis diferenciados. Em trabalho recente denominamos esse processo como "simbiose do capital" (MACIEL; VALLE, 2012).

A alteração macro-organizacional teve como momento inicial a formação de uma estrutura burocrática dentro do próprio SEBRAE, que ficou responsável pela elaboração de uma agenda de políticas produtivas, as quais seriam introduzidas primeiramente nas três maiores empresas oleiras da cidade de Iranduba. Nesse sentido, não se romperia radicalmente com a base produtiva anterior, caracterizada pela queima substancial de lenha. A transição seria lenta, gradual, tendo em vista o papel que a indústria oleira representa no cenário da construção civil manauense, em franca expansão desde meados da década de 2000.

No planejamento delineado pelogoverno, para se implementaresse conjunto de elementos industriais, seria necessário forjar um arranjo político-administrativo o qual, por um lado, apontasse para um caminho de desenvolvimento comum e, por outro, unisse os diferentes atores do envolvidos no processo (NEAPL, 2009). Concretamente, a ideia era "aproximar" os municípios dos "arredores" de Manaus, fazendo com que eles se tornassem "participantes dos benefícios econômicos e sociais oriundos da lógica produtiva da ZFM" (MACIEL; VALLE, 2011, p. 38). Estava assim criado o ambiente discursivo para se promover uma guinada política com profundas transformações no espaço rural/urbano amazonense, qual seja, a criação da Região Metropolitana de Manaus. Vejamos. 


\section{A CRIAÇÃO DA REGIÃO METROPOLITANA DE MANAUS}

O processo de urbanização da sociedade tem conduzido a uma verdadeira reorganização do espaço. Isso não quer dizer que o espaço sofra uma intervenção humana, tendo em vista a busca pela melhoria do conjunto dos indivíduos que o ocupam. Pelo contrário, o que se pode observar é que a urbanização tem como pano de fundo o ideal de progresso no sentido capitalista, de avançar, ainda que se tenha um grande ônus social. Este envolve tanto a destruição da natureza, quanto a segregação de classes sociais, tudo em nome do progresso.

A Amazônia, enquanto ambiente permeado por uma relação peculiar entre natureza e cultura, também tem sido palco desse movimento de transformações no espaço no sentido de torná-lo, cada vez mais, urbanizado. O que é interessante é que na apresentação que é feita da urbanização está embutida a ideia de que esse é o único sentido concreto para se chegar ao desenvolvimento humano e às suas potencialidades (CASTRO, 2008).

Logo, a representação que se dá ao espaço se constitui em um artifício político que tem como objetivo principal a legitimação de certas práticas que envolvam altos recursos financeiros e que coloquem em evidência o projeto de poder de grupos dominantes. No caso da Amazônia, em particular, a questão central é a derrubada de todas as barreiras espaciais vistas como empecilho ao progresso da região, ainda que, para isso, se tenha de fazer uso da manipulação, do discurso ideologicamente carregado e da má ação sobre natureza (LIMA, 2010).

Manaus, que desde a década de 1970 se tornou um grande centro industrial e comercial, incorre exatamente dentro dessa perspectiva, tendo a sua dinâmica econômica atrelada ao discurso da "cidade moderna", o qual levou a "metrópole da Amazônia" a um gigantesco inchaço urbano e, também, à própria "morte" urbana da natureza, corporificada nos aterros de igarapés, derrubada de áreas verdes e construção de condomínios residenciais.

A cidade entra numa lógica espacial voltada para o predomínio do espaço enquanto objeto de poder, quer dizer, onde o território passa a ser transformado não de acordo com o interesse público, mas em face da instauração de interesses de uma elite que define, em vários sentidos, o caminho do "planejamento" urbano. Esse é o ponto: um caminho ligado aos ideais dominantes, mas que é aberto pelo próprio Estado.

Não seria isso que está por trás, por exemplo, da criação da Região Metropolitana de Manaus (RMM)?

Criada em 30 de maio de 2007, a Região Metropolitana de Manaus teve seu elemento embrionário forjado na premissa de que era preciso aproximar de Manaus os municípios que estavam em seu entorno, distribuindo melhor os recursos provindos do modelo Zona Franca. Assim, oito municípios passaram 
a fazer parte desse processo de metropolização regional: Manaus, Careiro da Várzea, Iranduba, Manacapuru, Itacoatiara, Presidente Figueiredo, Novo Airão e Rio Preto da Eva, com uma população total de 2.175 .860 habitantes, e que registra um PIB de R\$36 bilhões (LIMA, 2010).

Ainda no ano de 2007, e como que simbolizando o início da RMM, começou a ser construída a Ponte Rio Negro, a qual foi inaugurada em 24 de outubro de 2011. Orçada inicialmente em R \$ 574 milhões, a construção da ponte foi finalizada somando um total de $\mathrm{R} \$ 1$ bilhão, sendo gasto quase o dobro do valor estimado. Tal obra revela, sobretudo, que tipo de desenvolvimento é pensado pelo Estado para a região, como também mostra o interesse que está por trás - mas que não aparecia na época do anúncio de criação da RMM e da Ponte Rio Negro - das transformações que são operadas no interior do próprio.

Basta observar os terrenos que estão sendo loteados do outro lado da ponte, na área rural do município de Iranduba. Além disso, também é possível visualizar a quantidade de novos condomínios residenciais à venda ao longo da AM-070, que liga Manaus a Manacapuru, que, em curtíssimo espaço de tempo, irão transformar a paisagem eminentemente rural daquela região.

O anúncio da Cidade Universitária também faz parte dos "benefícios" trazidos pela criação da RMM. Trata-se da construção do campus da Universidade do Estado do Amazonas (UEA), com previsão de início das obras em julho deste ano e término em 2014. Com investimento estimado em cerca de R\$300 milhões, segundo o governo do Amazonas, a obra beneficiará mais de 12 mil pessoas, entre alunos, professores e servidores.

Contudo, grande parte do projeto está destinada à iniciativa privada, com a concessão de espaços para hotéis, shoppings e resorts. Exemplo disso, é que, de acordo com o projeto original (Figura 3), toda a área de praia às margens do rio negro está reservada à construção de empreendimentos relacionados a prédios residenciais de luxo. À Cidade Universitária propriamente dita está reservado o interior do espaço destinado ao projeto.

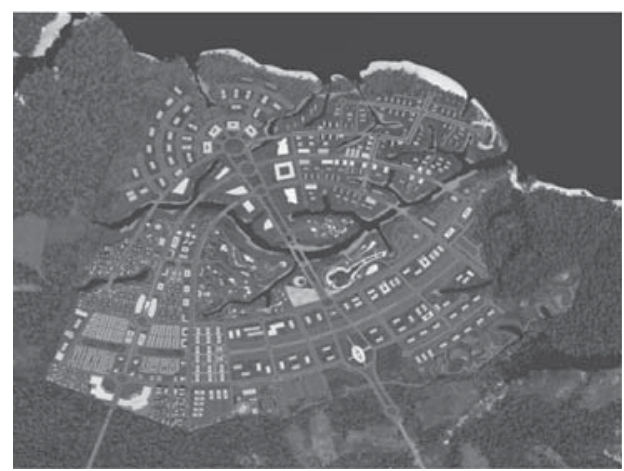

Figura 3. Cidade Universitária. Fonte: MACIEL, 2012.

Novos Cadernos NAEA, v. 16, n. 1, Suplemento, p. 127-162, nov. 2013 
De certa forma, é como se o governo quisesse mostrar a importância da Região Metropolitana de Manaus, implementando obras que a justifiquem perante a população amazonense. O que fica às claras é que a própria construção desses empreendimentos está sendo pautada numa lógica de distribuição do espaço de acordo com os interesses de grupos. No caso da Cidade Universitária, não houve consulta à população estudantil nem aos professores. No caso da Ponte Rio Negro, também não houve. E, no caso da criação da RMM, a tônica foi a mesma: impor aos cidadãos as decisões tomadas sob interesses obscuros.

O Estado não sabia que haveria loteamento das terras quando da inauguração da ponte? Não sabia que empresas iriam aterrar igarapés e desmatar áreas verdes para construir condomínios? Se se sabia e está permitindo tais práticas, fica patente que as intenções das mais diversas estavam permeando a concepção e a realização de obras como a Ponte e a Cidade Universitária. Se não se sabia, revela-se, concretamente, que estamos diante de um projeto de planejamento que não leva em conta o custo social e ambiental que se há de se arcar na elaboração e execução de projetos dessa natureza.

Quem realmente foi beneficiado não somente pela criação da RMM, mas também pelos projetos dela oriundos foram as olarias de Iranduba, que, em face da construção da Ponte, pôde ter maior acesso ao mercado da construção civil manauense, além de reduzir o custo com transporte de tijolos até Manaus, antes feito através de balsa. Acresce a isso, no caso do Projeto Cidade Universitária, a quantidade de tijolos que será necessária para se construir tal estrutura, o que demandará uma maior produção oleira e, consequentemente, mais lucros.

Em crise até meados de 2005, o setor oleiro passa a ter, em face disso, boas perspectivas para o futuro, associando demanda de mercado, ajuda do Estado e controle do trabalho. Tal relação constitui-se um elemento instigante e foi nosso foco de estudo realizado em uma das principais olarias da Região Metropolitana de Manaus. É o que será abordado a seguir.

\section{A EMPRESA E OS TRABALHADORES}

Das três empresas escolhidas pelo SEBRAE, a pesquisa que realizamos lançou seu foco sobre a que possuía a maior produção de tijolos e o maior número de trabalhadores empregados. Esta cerâmica localiza-se na AM-070 (que liga o distrito de Cacau-Pirêra a cidade de Manacapuru), no $\mathrm{km} \mathrm{36,} \mathrm{s/n,} \mathrm{Iranduba-}$ Amazonas. Fundada em 24/08/1989 por 2 sócios/proprietários, a Cerâmica CA1 possui uma área total de $16.000 \mathrm{~m}^{2}$, e de área construída, $6.400 \mathrm{~m}^{2}$. Como nos disse o proprietário da cerâmica, "foi uma olaria trocada por uma caminhonete". 


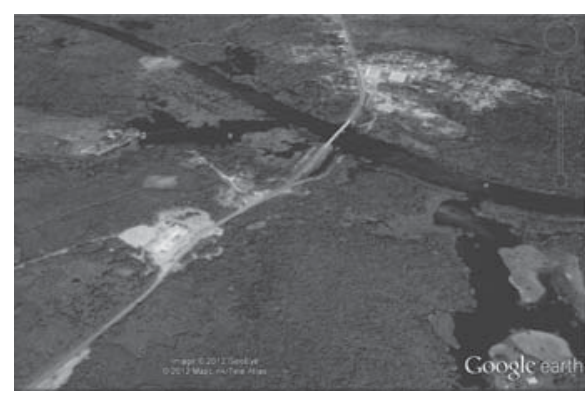

Figura 4. Localização da empresa pesquisada. Ao fundo vê-se o Rio Ariaú e a Vila do Ariaú. Fonte: Imagem de satélite. Google Earth, 2012.

A produção de tijolos na empresa gira em torno de 1 milhão de peças por mês (CERÂMICA CA1, 2011). Cada milheiro do tijolo é vendido às grandes construtoras de Manaus (principais clientes) ao preço de $\mathrm{R} \$ 380,00$ (trezentos e oitenta), em média. No que se refere ao faturamento mensal ou anual, a empresa preferiu não declarar, tendo em vista um posicionamento estratégico diante das demais empresas do setor cerâmico. Mas, na pesquisa de campo tivemos acesso aos gastos mensais da empresa, como mostra a Tabela 1.

Tabela 1. Gastos mensais da empresa

\begin{tabular}{l|c|c}
\hline Gastos (em média) & Valores (R\$) & Porcentagem (\%) \\
\hline Funcionários da produção & $\mathrm{R} \$ 40.000,00$ & 51,2 \\
\hline Funcionários da administração & $\mathrm{R} \$ 3.000,00$ & 3,8 \\
\hline Matéria-prima e insumos & $\mathrm{R} \$ 25.000,00$ & 32 \\
\hline Energia elétrica ou Biomassa & $\mathrm{R} \$ 10.000,00$ & 13 \\
\hline Total & $\mathbf{R} \$ \mathbf{7 8 . 0 0 0 , 0 0}$ & $\mathbf{1 0 0}$ \\
\hline
\end{tabular}

Fonte: Pesquisa de campo, 2012.

O quadro de funcionários da empresa é composto por 50 trabalhadores, o que a coloca como uma empresa de médio porte: 45 na parte da produção e 5 trabalhadores que ocupam-se da parte de administração/vendas. Desse total, os homens se constituem a maioria, sendo que apenas 5 mulheres fazem parte do quadro de trabalhadores. A Tabela 2 revela em porcentagem essa configuração, destacando na amostra da pesquisa a proeminência do sexo masculino no conjunto da força de trabalho.

Tabela 2. Sexo.

\begin{tabular}{l|c|c}
\hline Sexo & Quantidade & Porcentagem (\%) \\
\hline Masculino & 33 & 87 \\
\hline Feminino & 5 & 13 \\
\hline Total & $\mathbf{3 8}$ & $\mathbf{1 0 0}$ \\
\hline
\end{tabular}

Fonte: Pesquisa de campo, 2012.

Novos Cadernos NAEA, v. 16, n. 1, Suplemento, p. 127-162, nov. 2013 
No que se refere à idade dos trabalhadores, grande parte encontra-se na faixa etária dos 25 a 34 anos. Contudo, o que chama a atenção é o percentual de trabalhadores com idade acima de 45 anos (Tabela 3). Com efeito, conforme pudemos averiguar nas entrevistas, há trabalhadores na olaria com idade acima de 60 anos, o que, considerando as condições de trabalho no local, indica que estes senhores não encontram outras atividades nas quais sejam aceitos, daí procuram emprego nas olarias.

Tabela 3. Idade dos trabalhadores.

\begin{tabular}{l|c|c}
\hline Idade & Quantidade & Porcentagem (\%) \\
\hline Menos de 20 anos & 0 & 0,00 \\
\hline $20-24$ anos & 7 & 18,42 \\
\hline $25-34$ anos & 14 & 36,84 \\
\hline $35-44$ anos & 10 & 26,32 \\
\hline 45 anos ou mais & 7 & 18,42 \\
\hline Total & $\mathbf{3 8}$ & $\mathbf{1 0 0}$ \\
\hline
\end{tabular}

Fonte: Pesquisa de campo, 2012.

No que tange à escolaridade, o que nos chama a atenção é o baixo índice de pessoas analfabetas: 2,63\% dos entrevistados. Esse dado está ligado ao fato da empresa, no ato da contratação, preferir indivíduos que já tenham sido alfabetizados, uma vez que, segundo o dono da olaria,

[...] facilita a aprendizagem das exigências feitas a nós por técnicos em segurança no trabalho. Além disso, como queremos obter a ISO 9001, é fundamental termos pessoas minimamente capazes de lerem instruções, procedimentos e absorver a cultura organizacional (proprietário da olaria).

Outro dado instigante é a grande porcentagem de trabalhadores que estudaram até o Ensino Fundamental, cerca de 44\% (Tabela 4). Além disso, a quantidade de pessoas que não estão estudando é reveladora: todos os entrevistados não estavam estudando no ano de 2012. Esses dois índices indicam, de certa forma, o próprio grau de qualificação que se tem hoje na olaria, com trabalhadores com pouca escolaridade, os quais, por motivos diversos, não continuaram a estudar. No caso de Antônio (22 anos), a razão foi a necessidade de ajudar no sustento de casa, pois "a gente precisava de dinheiro, e como não tinha outra saída, tive que largar os estudos e me empregar na olaria". 
Tabela 4. Grau de escolaridade.

\begin{tabular}{l|c|c}
\hline Grau de Escolaridade & Porcentagem (\%) & Estudando Atualmente \\
\hline Nunca estudou & 2,63 & Não \\
\hline Só assina o nome & 13,16 & Não \\
\hline $1^{\mathrm{a}}$ a $4^{\mathrm{a}}$ série & 15,79 & Não \\
\hline $5^{\mathrm{a}}$ a $8^{\mathrm{a}}$ série & 44,74 & Não \\
\hline Ensino médio incompleto & 10,53 & Não \\
\hline Ensino médio completo & 13,16 & Não \\
\hline Total & $\mathbf{1 0 0}$ & Ninguém está estudando \\
\hline
\end{tabular}

Fonte: Pesquisa de campo, 2012.

Antes de serem empregados da olaria pesquisada, os trabalhadores da empresa desenvolviam atividades na cidade e no meio rural que podem ser elencadas conforme podemos ver na Tabela 5 :

Tabela 5. Atividade desenvolvida antes de trabalhar na empresa

\begin{tabular}{l|c|c}
\hline \multicolumn{1}{c|}{ Atividade } & Quantidade & Porcentagem (\%) \\
\hline Agricultor & 13 & 34,2 \\
\hline Trabalhava em outra olaria & 7 & 18,4 \\
\hline Carpinteiro & 3 & 7,8 \\
\hline Estudante & 4 & 10,5 \\
\hline Outras & 11 & 29 \\
\hline Total & $\mathbf{3 8}$ & $\mathbf{1 0 0}$ \\
\hline
\end{tabular}

Fonte: Pesquisa de campo, 2012.

A Tabela 6 mostra a porcentagem dos salários pagos aos trabalhadores, revelando que a maioria (94,74\%) recebe entre $\mathrm{R} \$ 601,00$ e $\mathrm{R} \$ 1200,00$. Já entre os que recebem até $\mathrm{R} \$ 600,00$, esse índice cai para 2,63\%. Uma possível explicação para esse valor talvez esteja na própria fala do trabalhador Fabrício (24 anos): "eu recebo por semana cento e cinquenta reais. O pessoal diz que é porque eu não sou carteira assinada". No caso dele, o salário mensal seria de $\mathrm{R} \$$ 600,00. "Mas tem a produção. Se eu cumprir a meta dada pelo gerente, eu ganho um valor maior no final de semana”, complementa Fabrício.

Tabela 6. Nível salarial.

\begin{tabular}{l|c|c}
\hline Salário & Quantidade & Porcentagem (\%) \\
\hline Até $\mathrm{R} \$ 600,00$ & 1 & 2,63 \\
\hline De $\mathrm{R} \$ 601,00$ a $\mathrm{R} \$ 1200,00$ & 36 & 94,74 \\
\hline De $\mathrm{R} \$ 1201,00$ a $\mathrm{R} \$ 1800,00$ & 1 & 2,63 \\
\hline De $\mathrm{R} \$ 1801,00$ a $\mathrm{R} \$ 2400,00$ & 0 & 0,00 \\
\hline De $\mathrm{R} \$ 2401,00$ a $\mathrm{R} \$ 3000,00$ & 0 & 0,00 \\
\hline Total & $\mathbf{3 8}$ & $\mathbf{1 0 0}$ \\
\hline
\end{tabular}

Fonte: Pesquisa de campo, 2012.

Novos Cadernos NAEA, v. 16, n. 1, Suplemento, p. 127-162, nov. 2013 
Conforme ainda mostra a tabela, o índice de trabalhadores que ganham entre $\mathrm{R} \$ 1201,00$ e $\mathrm{R} \$ 1800,00$ é de 2,63\%, o que representa em termos de número de trabalhadores apenas um indivíduo: o gerente da olaria. Pode-se falar, assim, que, de maneira geral, não há uma grande variação salarial na olaria, em face do próprio tipo de trabalho que lá se opera. O que pode diferenciar é o pagamento pela produção de cada setor. Por exemplo: se os forneiros conseguirem queimar 3 fornos de tijolos eles ganham um valor $x$, se não queimarem, ganham apenas o salário registrado em carteira.

Tal estratégia da empresa se configura como uma forma disfarçada de extração de mais-valia. O aumento da produtividade não se dá pela extensão direta do período de trabalho, mas da capacidade de organização do processo de trabalho para se atingir a meta da semana. Em outras palavras, há uma pressão no interior da produção para se produzir mais, contudo, é uma pressão apresentada enquanto uma simples "meta". Na verdade, conforme se pode perceber na pesquisa de campo, o pagamento pela produtividade é apresentado ao trabalhador como se fosse um bônus, uma vez que eles não "precisam" fazer hora-extra para ganhar mais. Basta cumprir a meta da semana.

Não obstante, o que está escondido no argumento da empresa, e para o qual Marx já nos alertava, é que as formas de subsunção real do trabalho ao capital ocorrem não apenas mediadas pela introdução de máquinas e equipamentos, mas também pelo jogo ideológico que se injeta no tecido produtivo e que implica na valorização do capital (MARX, 1985). Tal jogo ideológico é caracterizado na empresa pelo discurso do "ganho pela produção", constituindo enquanto uma ferramenta para se extrair mais-valor da força de trabalho, sem que se perceba o real interesse da empresa: a busca por lucro e controle do trabalho.

Assim, em face da busca pela maior produtividade da mão de obra utilizando-se do período normal de trabalho na empresa, esta usa tal ferramenta para dizer que se faz pouca hora-extra na olaria. Com efeito, os próprios trabalhadores assumiram para si essa ideia, conforme podemos ver na Tabela 7 , onde mais de 50\% afirmam nunca fazer hora-extra. Nas palavras de Joaquim (36 anos), "[...] aqui o pessoal não costuma fazer hora-extra, não. Tem uns que faz, mas é só uns dois ou três”.

Tabela 7. Frequência de hora-extra.

\begin{tabular}{l|c|c}
\hline Frequência de Hora Extra & Quantidade & Porcentagem (\%) \\
\hline Segunda a sexta & 1 & 2,63 \\
\hline Quase todo dia & 5 & 13,16 \\
\hline Fim de semana & 0 & 0,00 \\
\hline Um dia na semana & 10 & 26,32 \\
\hline Nunca & 22 & 57,89 \\
\hline Total & $\mathbf{3 8}$ & $\mathbf{1 0 0}$ \\
\hline
\end{tabular}

Fonte: Pesquisa de campo, 2012.

Novos Cadernos NAEA, v. 16, n. 1, Suplemento, p. 127-162, nov. 2013 
Com base nos dados apresentados na Tabela 7, poder-se-ia concluir que, em sua maioria, os trabalhadores da olaria não trabalham um tempo adicional para a empresa. Contudo, em face da introdução do pagamento pela produtividade, esse tempo adicional é incorporado ao tempo normal do trabalho. Assim, a olaria lucra de três formas: a) aumentando a produção de tijolos sem que se recorra à hora-extra tradicional; b) apresentando-se aos órgãos de fiscalização e à sociedade enquanto uma empresa com baixos índices de tempo adicional de trabalho; c) definindo o valor que será pago pelo cumprimento das metas, já que isto fica a cargo da empresa, e não das leis trabalhistas, que seria o caso das horas-extras.

Ora, isto revela, sobremaneira, o controle que se tem sobre o trabalho e a guinada ideológica que se opera no interior do processo de trabalho. Quer dizer, os trabalhadores são motivados a trabalhar, a darem "o melhor de si", para ganhar a tão proclamada "produção". Contudo, nas entrelinhas da lógica discursiva da empresa, o que se está pregando é que tal pagamento, na verdade, é um bônus da empresa àqueles trabalhadores que se empenham e cumprem as metas estabelecidas, metas estas que são estabelecidas pela própria gerência da olaria, e não pelo conjunto da mão de obra.

Tal análise é corroborada pela fala de um dos trabalhadores ao me relatar o medo que tinha medo de não cumprir as metas e, nesse sentido, não receber o pagamento pela produção. Segundo ele,

[...] o patrão diz pra gente qual é a meta da semana, aí a gente faz nossa parte pra cumprir. Mas o ruim é que se a gente não produzir o tanto que disseram, a gente fica sem receber o pagamento, e recebe só o que tá na carteira mesmo. Tem semana que eu fico com medo de não receber, porque é assim mesmo: se a gente não cumprir a meta ele [o patrão] não paga não. (Mauro, 33 anos, forneiro).

Esse relato mostra, em certo sentido, o grau de expropriação de mais-valia sobre o trabalho, além de trazer à tona o tipo de estratégia empresarial utilizada no interior do processo de trabalho: o uso do conhecimento e do desconhecimento operário. Explico: do conhecimento, posto que são os trabalhadores que possuem o capital intelectual para saber lidar com o barro, para objetivarem na matéria-prima aquilo que aprenderam na relação com seu próprio trabalho; do desconhecimento, uma vez que eles, possuidores do saber fazer, são impelidos por uma carga ideológica de que o pagamento pelas metas é uma espécie de dádiva da empresa. Assim, são explorados duplamente sem saber. Expropriados, crentes que o empenho oferecido foi usado em favor deles mesmo.

Em outras palavras, o trabalhador se esforça para cumprir as metas da produção, e não a cumprindo, nada recebe. Mas isso não anula o fato de eles terem se esforçado para alcançá-las. Não exclui o trabalho humano que foi despendido, e que gera mais-valia para o dono da olaria. Dito de forma enfática, trata-se de 
dispêndio de força de trabalho humano que deveria ser paga, independentemente do cumprimento ou não das metas. Estas não deveriam ser a condição necessária para o recebimento do pagamento, mas sim, o próprio trabalho humano objetivado no processo de produção de tijolos. Na olaria ocorre o inverso disso: a força de trabalho empregada é o elemento contingente, e o atingir as metas, o necessário.

\section{AS CONDIÇÕES DE TRABALHO}

As condições de trabalho na empresa são visivelmente precárias. Conforme podemos observar na Tabela 8 , há a predominância da opinião daqueles que avaliam as condições de trabalho como mais ou menos, o que revela um nível de descontentamento por parte dos trabalhadores, mas que é "suportável".

Tabela 8. As condições de trabalho.

\begin{tabular}{l|c|c}
\hline Condições de Trabalho & Quantidade & Porcentagem (\%) \\
\hline Ótima & 4 & 10,53 \\
\hline Boa & 12 & 31,58 \\
\hline Mais ou Menos & 21 & 55,26 \\
\hline Ruim & 0 & 0,00 \\
\hline Péssimo & 1 & 2,63 \\
\hline Total & $\mathbf{3 8}$ & $\mathbf{1 0 0}$ \\
\hline
\end{tabular}

Fonte: Pesquisa de campo, 2012.

A principal reclamação dos trabalhadores em relação às condições de trabalho diz respeito à temperatura do ambiente de trabalho. De fato, quando se adentra o espaço da produção de tijolos, sente-se "na pele" o calor que emana dos fornos e se espalha por toda olaria. Como não há sistema de ventilação, os trabalhadores têm de suportar o calor.

Os fornos da olaria atingem uma temperatura média de $1500{ }^{\circ} \mathrm{C}$, e como há 12 fornos que, alternadamente, estão sempre queimando tijolos, não há momento de temperatura amena nas instalações da fábrica. Mesmo à noite, a temperatura continua alta.

Paralela ao alto nível de temperatura há o problema da fumaça que sai dos fornos quentes. Esta é ocasionada pela queima de caixas de madeiras e papelões, bem como pela queima de pó de serragem e pedaços de madeira provindos das casas do Programa Prosamim ${ }^{13}$. Os trabalhadores relatam que essa fumaça provinda dos fornos tem ocasionado o aparecimento de doenças, como dor nos olhos, dificuldade ao respirar e dor na garganta.

Nas visitas que efetuamos era possível visualizar nuvens de fumaça que

13 Programa Social e Ambiental dos Igarapés de Manaus. O objetivo dessa ação governamental é ajudar na solução dos problemas ambientais, urbanísticos e sociais das famílias que vivem às margens dos principais igarapés de Manaus.

Novos Cadernos NAEA, v. 16, n. 1, Suplemento, p. 127-162, nov. 2013 
pairavam pelo teto da fábrica, não obstante haver chaminés que são colocadas sobre os fornos para lançarem a fumaça a uma altura de 40 metros. Contudo, essas chaminés não captam a totalidade da fumaça, e esta acaba ficando "presa" dentro da fábrica.

Tal situação traz consequências à saúde dos trabalhadores, como aponta Seu Lenilson (50 anos):

Os forno não para, é direto aí. Fica queimando a semana toda. Aí a fumaça continua junto também. A gente vevi com problema na garganta, e com os olhos ardendo. Mas não tem outro emprego, a gente continua nesse aqui. [...] Seria bom se a fumaça fosse menor, e a quentura também. E como a gente tem que usar esse macacão, aí fica mais quente ainda.

O macacão do qual Seu Lenilson fala é a roupa que os trabalhadores usam durante o expediente de trabalho. Segundo o proprietário da olaria,

[...] essa roupa grossa foi uma própria reivindicação deles (os trabalhadores).

Antes a gente dava uma roupa fina, menos quente, mas eles reclamavam que rasgava rápido. Então nós compramos essa que eles estao vestidos aí. Agora eles reclamam dizendo que ela é pesada e quente (proprietário da olaria).

A questão central para os trabalhadores é que a roupa grossa, associada à temperatura da região amazônica, juntamente com a temperatura dos fornos, cria um ambiente de trabalho que se torna humanamente desconfortável, daí os trabalhadores apontarem para a insatisfação quanto às condições de trabalho na empresa. Além disso, há o fato de existirem espaços da fábrica que ainda não possuem cobertura, fazendo com que alguns setores da produção operem debaixo do sol e, muitas vezes, sob a chuva.

No que concerne ao ritmo de trabalho na empresa, conforme mostra a Tabela 9, a maioria dos trabalhadores é da opinião de que o ritmo do trabalho está na medida certa $(73 \%)$. Contudo, a porcentagem de trabalhadores que afirmam que o ritmo de trabalho é rápido ou muito rápido também é representativa (mais de $26 \%$ ).

Tabela 9. Ritmo de trabalho.

\begin{tabular}{l|c|c}
\hline Ritmo de Trabalho & Quantidade & Porcentagem (\%) \\
\hline Muito Rápido & 3 & 7,89 \\
\hline Rápido & 7 & 18,42 \\
\hline Na medida certa & 28 & 73,68 \\
\hline Lento & 0 & 0,00 \\
\hline Total & 38 & 100 \\
\hline
\end{tabular}

Fonte: Pesquisa de campo, 2012. 
Uma possível explicação: quando estabelecemos uma relação entre as repostas dos trabalhadores sobre o ritmo de trabalho e a função que eles exercem na empresa, emerge um dado interessante: os que trabalham no processo de enforna e desenforna e de manipulação da biomassa são os que avaliam o trabalho na empresa como rápido e muito rápido. Todos os trabalhadores desses processos da divisão do trabalho fábrica são da opinião de que eles trabalham em um ritmo além do que seria considerado normal.

Como se trata da última etapa do processo de fabricação de tijolos, e também por ser a que necessita de um tempo maior para ser finalizada, a queima dos tijolos se configura como o momento-chave para a empresa. Assim, é nessa etapa que paleteiros, enfornadores, forneiros e desenfornadores são cobrados para otimizarem cada momento do processo de queima. No caso dos paleteiros, o ritmo de trabalho torna-se mais rápido, de modo a não deixar que falte material para a queima. Como não se pode diminuir as chamas dos fornos, sob risco de trincar os tijolos, tais trabalhadores são compelidos a acelerar o ritmo de trabalho.

Em relação aos forneiros, o ritmo é intenso, principalmente nas primeiras 24 horas de queima, quando a temperatura dos fornos precisa atingir o nível máximo. É nesse momento que se tem de lançar ao forno uma quantidade grande de biomassa, num ritmo que não deixe a temperatura diminuir.

Já os desenfornadores têm um ritmo acelerado quando a demanda por tijolos está muito alta (o que acontece atualmente, face ao aquecido mercado imobiliário manauense). Neste caso, o trabalho torna-se "puxado"14 tendo em vista a necessidade de se encherem de tijolos os caminhões que irão entregá-los tijolos aos clientes.

Paralelo ao ritmo de trabalho na empresa, o qual, na própria opinião dos trabalhadores, é considerado alto, está o trabalho em posição desconfortável. Tal item significa, concretamente, o desenvolvimento de atividade fabril em uma posição que causa desconforto ao corpo, ocasionando ou não algum tipo de lesão.

A Tabela 10 mostra que mais da metade dos trabalhadores oleiros (63\%) trabalham em posições desconfortáveis, e que, por seu turno, trazem incômodo durante o processo de trabalho.

Uma explicação para tal índice de desconforto no trabalho talvez esteja no fato de, na maior parte do tempo, os trabalhadores desenvolverem suas atividades em pé, levando, em face disso, a dores na coluna e nas pernas. Outro fator que contribui para esse desconforto talvez seja a quantidade de vezes, por exemplo, que os desenfornadores e enfornadores precisam agachar e levantar para tirar os tijolos dos fornos e colocá-los no carrinho que levará esses tijolos para o pátio da empresa.

14 Termo usado pelos próprios trabalhadores, significando que o trabalho tem de ser realizado com mais rapidez e afinco.

Novos Cadernos NAEA, v. 16, n. 1, Suplemento, p. 127-162, nov. 2013 
Tabela 10. Trabalho em posição desconfortável

\begin{tabular}{l|c|c}
\hline \multicolumn{1}{c|}{ Período } & Quantidade & Porcentagem (\%) \\
\hline Todo o tempo & 10 & 26,32 \\
\hline Grande parte do tempo & 6 & 15,79 \\
\hline Metade do dia & 4 & 10,53 \\
\hline Pequena parte do dia & 4 & 10,53 \\
\hline Nunca & 14 & 36,84 \\
\hline Total & $\mathbf{3 8}$ & $\mathbf{1 0 0}$ \\
\hline
\end{tabular}

Fonte: Pesquisa de campo, 2012.

De fato, os desenfornadores e enfornadores eram o que mais reclamavam de dores pelo corpo em face de, segundo eles, "o trabalho ser pesado". O caso do Seu Sebastião, 56 anos, enfornador e morador de Manacapuru, é um exemplo revelador dessas reclamações:

[...] O trabalho é um pouco pesado. E para piorar, a gente fica muito tempo em pé. Aí tem hora que o corpo da gente que já estamos há muito tempo no serviço aqui cansa. Eu mesmo já peguei uma hérnia na virilha, mas estou trabalhando mesmo assim. Eu preciso, né? Fora eu, tem outros companheiros da olaria aí que estão com problema de hérnia também [...].

Nas entrevistas que realizamos foi possível comprovar o que Seu Sebastião havia comentando. Com efeito, dois trabalhadores confirmaram que já haviam sido diagnosticado com hérnia, e outros três reclamaram de dores no abdômen, suspeitando que se tratava de hérnia. Todos esses trabalhadores tinham idade acima de quarenta anos, e estavam há mais de 10 anos na atividade oleira.

Tais dados são corroborados ainda pela quantidade de trabalhadores que se sentem cansados no trabalho, qual seja, quase $87 \%$. Já o índice daqueles que afirmam não se sentirem cansados no trabalho é de 13\%. O interessante é que, quando comparamos esse último índice com o tempo de trabalho na empresa e com a idade dos trabalhadores, observa-se uma relação direta entre as variáveis, ou seja, todos os que dizem nunca se sentirem cansados têm menos de 30 anos de idade e menos de 5 anos na empresa. Já aqueles que têm idade acima dos 30 anos e mais de 5 anos na empresa são da opinião de que se sentem cansados.

Tabela 11. Frequência de cansaço no trabalho.

\begin{tabular}{l|c|c}
\hline \multicolumn{1}{c|}{ Período } & Quantidade & Porcentagem (\%) \\
\hline Todos os dias & 7 & 18,42 \\
\hline A maioria dos dias & 2 & 5,26 \\
\hline Metade do tempo & 3 & 7,89 \\
\hline Alguns dias & 21 & 55,26 \\
\hline Nunca & 5 & 13,16 \\
\hline Total & $\mathbf{3 8}$ & $\mathbf{1 0 0}$ \\
\hline
\end{tabular}

Fonte: Pesquisa de campo, 2012.

Novos Cadernos NAEA, v. 16, n. 1, Suplemento, p. 127-162, nov. 2013 
Esse conjunto de dados mostra, nessa perspectiva, que existe uma relação causal entre o tipo de trabalho que é desenvolvido na olaria, o tempo de trabalho e o trabalho em posição desconfortável, fornecendo, assim, um quadro das condições de trabalho e as implicações destas para a saúde e o bem-estar dos trabalhadores. Estes, não obstante serem acostumados ao trabalho braçal, apontam para níveis de cansaço e de ritmo de trabalho que fogem ao modo como os trabalhadores organizavam e produziam sua existência no interior do estado.

Talvez esse seja o ponto-chave, quer dizer, a dissociação que se tem entre o tempo de trabalho e de não trabalho no interior, no meio rural, face à introdução da indústria nesse meio. Como os trabalhadores oleiros são, em sua maioria, provenientes do ambiente rural e ligados à agricultura, o modo de produzir sua existência não "anda de mãos dadas" com a lógica produtiva para o mercado, típico do capitalismo. Neste, postula-se um ritmo de trabalho no qual o padrão de tempo de produção não é estabelecido pela classe trabalhadora, mas pela exigência da demanda do mercado.

Em face disso, o processo de trabalho no interior da fábrica precisa ser, cada vez mais aperfeiçoado, no sentido de otimizar o tempo, fazendo com que o trabalhador ofereça mais de si às artimanhas dos donos dos meios de produção. No caso da olaria, a demanda por tijolos tem sido crescente nos últimos anos. $\mathrm{Na}$ verdade, existe um desnível entre oferta e demanda, sendo que esta última é muito maior do que a primeira, o que representa um déficit de tijolos em torno de $15 \%$ por ano (ACERAM, 2012).

Dentro da lógica do empresariado oleiro, quanto mais se produzir tijolos, maior será a taxa de lucro, já que existe uma margem no mercado que permite manter o preço do tijolo a um preço alto. Para se conseguir tal propósito, institui-se na olaria um tempo de trabalho que é alimentado pela concessão de um "bônus" aos trabalhadores (o pagamento pela produção). Essa estratégia empresarial leva o trabalhador a produzir mais em menor tempo. Em uma palavra, produz maisvalia, e o empresário sai ganhando.

Contudo, esse ganho do empresário implica necessariamente em perdas para o trabalhador, que vai muito além do seu bolso. Ele atinge o próprio corpo daquele que trabalha, já que, dentro do atual estágio do processo de trabalho oleiro, o trabalho material é realizado na sua forma mais elementar, fazendo-se uso, portanto, da força dos músculos do conjunto da mão de obra. Expostos a um ritmo de trabalho rápido e a um esforço braçal constante, os músculos cansam, e com o passar do tempo, tendem à exaustão.

Seria preciso uma análise médica para se chegar a uma avaliação precisa sobre o assunto, mas, por hipótese, é possível dizer que as hérnias às quais alguns trabalhadores fizeram referência tenham surgido como resultado do esforço a que eles são submetidos, tendo que, por exemplo, carregar pesado carros cheios de tijolos e, depois, tirá-los para colocar no forno. Esse processo, repetindo-se

Novos Cadernos NAEA, v. 16, n. 1, Suplemento, p. 127-162, nov. 2013 
no dia a dia, pode levar a uma lesão por esforço repetitivo (LER), e comprometer a saúde do trabalhador. Aqui, a palavra esforço deve ter destaque especial, posto que não se trata de esforço tão somente por repetir uma ação, mas por repetir uma ação na qual se despende uma alta carga de energia muscular à realização da atividade.

\section{A IMAGEM DA EMPRESA E A PRESSÃO NO TRABALHO}

Para se construir um quadro de como a imagem da empresa é vista pelos trabalhadores, e como estes avaliam a pressão da empresa sobre eles, levamos em consideração as seguintes opiniões: valorização do trabalho, relação empresa-trabalhador, pressão no ambiente de trabalho, preocupação com o trabalho dentro e fora dele, e felicidade no emprego atual.

Com efeito, dentro da relação capital-trabalho as empresas procuram estabelecer uma imagem de si para o trabalhador, no sentido de que este as veja enquanto parte de uma parceria pelo bem comum. Nessa lógica, postula-se que empresa e trabalhadores possuem os mesmos ideais, e caminham na mesma direção, não existindo o antagonismo de interesses (ALVES, 2010).

Isso é de suma importância à análise aqui realizada uma vez que é através da transmissão de certa imagem da empresa aos trabalhadores que ocorre a legitimação da exploração e do controle do trabalho. É no interior da aparência do fenômeno que reside a contradição (MARX, 2007). Contudo, concretamente, é exatamente o interior da aparência, ou seja, a essência da realidade que o capitalista busca ocultar. Como uma espécie de ilusionista, o empresário usa um conjunto de estratégias para mostrar aquilo que poderíamos chamar de "chão de fábrica fabricado". Mais precisamente, relações de produção onde se nega o conflito (ANTUNES, 2009).

Isso significa, portanto, que é na própria construção de uma pseudo harmonia entre empresas e trabalhadores que reside a justificativa, ou melhor, a reprodução de determinada pressão no trabalho, a qual se torna como algo inerente à estrutura produtiva, e não como contingente. A pressão naturalizase, e é vista por grande soma de trabalhadores enquanto parte do processo de trabalho (ALVES, 1999).

É essa lógica que vem permeando substantivamente a relação empresatrabalhadores na empresa pesquisada. Ela é profícua para ajudar a explicar, por exemplo, a porcentagem de trabalhadores que, mesmo diante de condições de trabalho expostas no tópico anterior, dizem ter orgulho de trabalhar na empresa. Entende-se aqui por "orgulho" a ideia de se "vestir a camisa", de ter satisfação pessoal em fazer parte do corpo de empregados da fábrica. 
Na Tabela 12 podemos ver que mais da metade dos indivíduos diz ter orgulho de trabalhar na empresa (63\%). Esses trabalhadores têm mais de 25 anos e mais de 5 anos de casa. Quando perguntamos o porquê se sentiam orgulhosos, a resposta mais comum era que a empresa "dava trabalho" e concedia o pagamento pela produção $(75 \%)$. A porcentagem restante $(25 \%)$ direcionava a Deus a razão do orgulho em trabalhar na empresa, dizendo que Deus era quem tinha dado o trabalho, e que por isso se sentiam orgulhosos de trabalharem lá.

Tabela 12. Orgulho de trabalhar na empresa.

\begin{tabular}{l|c|c}
\hline \multicolumn{1}{c|}{ Orgulho } & Quantidade & Porcentagem (\%) \\
\hline Sim & 24 & 63,16 \\
\hline Não & 12 & 31,58 \\
\hline Não sei & 2 & 5,26 \\
\hline Total & $\mathbf{3 8}$ & $\mathbf{1 0 0}$ \\
\hline
\end{tabular}

Fonte: Pesquisa de campo, 2012.

Tal relação entre a religiosidade e percepção que se tem no tocante ao trabalho é interessante, e revela o papel que a religião representa na formação do homem do campo. Em certo sentido, mostra que determinada crítica ao processo de trabalho é afugentada pela ideia que se postula a respeito de Deus. Este emerge enquanto consolo às próprias condições e ao ritmo de trabalho, como que se fosse da vontade dEle que o capital sujeitasse o trabalhador e o alienasse no processo produtivo.

Dos que diziam que não sentiam orgulho, 90\% era composto por jovens até 25 anos e tinham menos de 5 anos de casa. Tais trabalhadores afirmavam que a falta de orgulho devia-se ao fato do trabalho não ser o que seria o ideal, e pensavam, em face disso, em conseguir outro emprego. Conforme relata Alberto (24 anos):

É difícil ter orgulho de um trabalho desse, né? Eu poderia estar em Manacapuru empregado em algum outro emprego. Mas aí, não deu. Eu vim parar aqui. Mas estou só esperando aparecer outra oportunidade de trabalho melhor que eu vou sair, cara. Isso não é vida para mim não [...].

Pelo que se vê, aqueles que são mais jovens e com menos tempo de trabalho têm uma postura mais crítica em relação ao orgulho do emprego. Já os que têm mais tempo de casa e mais idade, comportam-se de forma menos crítica, mostrando certo "conformismo" face às condições de trabalho da empresa, por exemplo.

Além disso, observa-se o próprio peso que a ideia do "bônus", o pagamento pela produção, assume na conformação do orgulho no trabalho. Tal estratégia empresarial mostra-se eficiente na postulação de uma falsa dádiva da

Novos Cadernos NAEA, v. 16, n. 1, Suplemento, p. 127-162, nov. 2013 
empresa para o trabalhador, uma vez que este vê essa lógica como verdadeira, e acaba por enxergar na empresa uma benfeitora, quando, na verdade, ela lhe extrai a mais-valia.

No que se refere à relação empresa-trabalhador, a maioria dos indivíduos considera como "mais ou menos" a forma com que o dono da empresa se relaciona com eles. De maneira geral, os trabalhadores reclamam que o chefe é "grosso", e que não "tem papas na língua". Esse dado mostra que os trabalhadores fazem uma divisão entre a empresa e o chefe, uma vez que eles dizem ter orgulho de trabalhar na empresa, mas não tem orgulho de trabalhar para o chefe. A figura do chefe "mandão", que é capaz de "demitir num piscar de olhos" (Seu Agnaldo, 39 anos) assusta os trabalhadores - daí mais de 55\% destes serem da opinião que a relação entre o empregador e os trabalhadores não é tão boa.

Tabela 13. Opinião sobre a relação empregador-trabalhador.

\begin{tabular}{l|c|c}
\hline Relação Empregador/Trabalhador & Quantidade & Porcentagem (\%) \\
\hline Ótima & 3 & 7,89 \\
\hline Boa & 14 & 36,84 \\
\hline Mais ou menos & 17 & 44,74 \\
\hline Ruim & 1 & 2,63 \\
\hline Péssima & 3 & 7,89 \\
\hline Total & $\mathbf{3 8}$ & $\mathbf{1 0 0}$ \\
\hline
\end{tabular}

Fonte: Pesquisa de campo, 2012.

Segundo os trabalhadores, falta compreensão do chefe quando, por exemplo, algum trabalhador não consegue ir trabalhar por causa de algum problema pessoal ou por doença. Além disso, reclamam que o chefe é radical, cortando o pagamento pela produção quando do não cumprimento das metas.

Em face disso, é razoável pensar que os trabalhadores se sentem pressionados pela empresa e, mais precisamente, pelo chefe deles. Como mostra a Tabela 14, esse índice chega a mais de 94\%, revelando um nível de pressão alto sobre os trabalhadores. Tal pressão se expressa nas exigências que são feitas, como falamos anteriormente, aos indivíduos que trabalham nos setores de enfornagem e desenfornagem, paletagem e embarque de tijolos.

O interessante é que esse último setor sofre uma pressão não somente por parte da empresa em si, mas também diretamente dos clientes. Explicamos: como, em muitas vezes, são os clientes que vão com seus carros comprar tijolos na olaria, eles acabam por participar enquanto "supervisores" do processo de trabalho, ficando, de certa forma, no controle indireto dessa atividade. É o que explica Tiago (29 anos, setor de embarque), ao falar do momento do embarque dos tijolos nos carros dos clientes: 
A gente embarca tijolos todo dia, de manhã e de tarde. O pessoal (clientes) chegam aí com caminhão ou pick-up para comprar tijolos. Aí a gente vai encher os carros deles. Tem uns que são esticados e ficam pedindo para gente ser mais rápido, ou ficam dizendo para a gente pegar um tijolo ao invés de outro. Aí pensa: já cansa, e ainda tem gente no pé do ouvido falando $[\ldots]$.

Tabela 14. Nível de pressão da empresa sobre o trabalhador.

\begin{tabular}{l|c|c}
\hline Nível & Quantidade & Porcentagem (\%) \\
\hline Alto & 12 & 31,58 \\
\hline Mais ou menos & 17 & 44,74 \\
\hline Baixo & 7 & 18,42 \\
\hline Baixíssimo & 0 & 0,00 \\
\hline Inexistente & 2 & 5,26 \\
\hline Total & $\mathbf{3 8}$ & $\mathbf{1 0 0}$ \\
\hline
\end{tabular}

Fonte: Pesquisa de campo, 2012.

A pressão no trabalho pode não se resumir apenas ao local de trabalho, mas para além da fábrica, permeando a vida íntima do trabalhador. Nessa perspectiva, foi também do meu interesse inquirir acerca dessa espécie de "pressão sobre a vida" do operário, que se revela na preocupação dele com o trabalho da empresa estando fora dela. Os dados estão postos na Tabela 15.

Tabela 15. Preocupação com o trabalho quando fora do ambiente fabril.

\begin{tabular}{l|c|c}
\hline Nível de Preocupação & Quantidade & Porcentagem (\%) \\
\hline Alto & 8 & 21,05 \\
\hline Mais ou menos & 8 & 21,05 \\
\hline Pouco & 7 & 18,42 \\
\hline Muito Pouco & 0 & 0,00 \\
\hline Inexistente & 15 & 39,47 \\
\hline Total & $\mathbf{3 8}$ & $\mathbf{1 0 0}$ \\
\hline
\end{tabular}

Fonte: Pesquisa de campo, 2012.

Os dados mostram que mais de 60\% dos trabalhadores têm algum tipo de preocupação com o trabalho da olaria quando não estão no espaço fabril. No caso dos paleteiros, suas preocupações se referem ao labor a céu aberto, levandoos a ficarem inquietos sobre o trabalho no sol ou na chuva no dia seguinte. Os forneiros dizem ficar preocupados em relação ao trabalho de outros forneiros que vão lhes suceder na queima dos tijolos, ou seja, se eles conseguirão atingir a meta estipulada, e entregar os tijolos prontos no prazo correto.

No caso daqueles que são oriundos de Manacapuru, mas que residem no prédio ao lado da olaria, a preocupação é ainda maior, uma vez que, em certo Novos Cadernos NAEA, v. 16, n. 1, Suplemento, p. 127-162, nov. 2013 
sentido, não possuem uma vida "fora do trabalho", e não têm uma relação direta com a família ou o convívio social que eram acostumados a ter na cidade. A "família" são os colegas de trabalho que ficam a semana toda na hospedaria, de sorte que grande parte das conversas que são travadas entre eles está relacionada ao próprio ambiente de trabalho.

Nessa perspectiva, tais indivíduos levam o trabalho para "casa", e passam a ter uma rotina diária de preocupação, principalmente no tocante ao número de vezes que trabalharam por produção. À noite, os trabalhadores pegam seus "caderninhos" e anotam seus respectivos períodos de tempo que trabalharam sob esse tipo de regime de trabalho. É comum vê-los contando uns para os outros quanto esperam ganhar em face da produção que realizaram durante a semana, ou reclamando se o chefe irá realmente pagar conforme ele havia falado.

Isso aponta, concretamente, para um tipo de solidariedade entre os trabalhadores, que é pautada pela preocupação com o trabalho, pelas promessas da gerência, e não pela vida em seu sentido mais amplo. Portanto, há um constrangimento da empresa sobre o trabalhador - me refiro aqui ao fato de hospedá-los ao lado da própria empresa - que os faz não ter uma relação social livre das amarras do capital.

Pelo contrário, o que ocorre é uma lógica de controle do trabalho, que atravessa a linha divisória entre tempo de trabalho e tempo de não-trabalho. Assim, a preocupação com o trabalho emerge como um elemento do capital que aflora em um momento em que teoricamente deveria ser dedicado não ao trabalho alienado, típico do capitalismo, mas à vida, à família, em suma, às relações sociais não intermediadas pela lógica da empresa. Infelizmente, não é isso que acontece e, em face disso, o capital tem levado vantagem, constrangendo os diversos momentos da vida do trabalhador oleiro.

Ainda como parte do estudo da pressão no trabalho, buscamos avaliar a questão do desemprego. Mais precisamente, o medo de perder o emprego. Os dados são interessantes: quase $80 \%$ dos trabalhadores dizem não ter medo de sair da empresa. Já entre os que dizem ter medo esse índice fica em torno de $20 \%$.

Tabela 16. Medo de perder o emprego.

\begin{tabular}{l|c|c}
\hline Medo & Quantidade & Porcentagem (\%) \\
\hline Muito medo & 2 & 5,26 \\
\hline Mais ou menos & 6 & 15,79 \\
\hline Não tem medo & 30 & 78,95 \\
\hline Total & $\mathbf{3 8}$ & $\mathbf{1 0 0}$ \\
\hline
\end{tabular}

Fonte: Pesquisa de campo, 2012.

Quando fomos averiguar que tipo de trabalhador fazia parte, desses dois grupos respectivamente, verificou-se que os que integravam o primeiro perfil 
- que não têm medo de perder o emprego - eram trabalhadores acima de 30 anos, há mais de 1 ano na empresa e que moram no meio rural. Do lado do segundo perfil - os que têm medo de perder o emprego - encontravam-se os trabalhadores de até 30 anos de idade, com menos de 1 ano na empresa e que moram em Manacapuru.

Perguntados por que não tinham medo de perder o emprego, os trabalhadores responderam que tão logo saíssem do emprego atual, conseguiriam trabalho em outra olaria, ou, então, voltariam às atividades ligadas à agricultura. Já os que tinham medo de perder o emprego, responderam que se saíssem da empresa não conseguiriam emprego em Manacapuru, e ficariam desempregados.

Esses dados revelam, pelo menos, três questões fundamentais:

Em primeiro lugar, mostra que os trabalhadores oleiros que vivem no meio rural não se sentem presos à olaria em termos de empregabilidade pois são, em sua maioria, "antigos" agricultores que ainda possuem terreno rural. Além disso, têm vínculos com parentes que cultivam diversas frutas e tubérculos amazônicos em seus respectivos terrenos. Em outras palavras, estão envoltos por um laço de relações de solidariedade que lhes permite ter certa tranquilidade no que diz respeito às condições materiais e espirituais de existência.

Em determinado sentido, não seria errôneo dizer que se trata de trabalhadores pluriativos, posto desenvolverem, principalmente aos sábados e domingos, atividades ligadas ao mundo rural, o que lhes proporcionam, por conseguinte, uma forma de não dependerem estritamente do trabalho oleiro.

Em segundo lugar, os dados manifestam o grau de não inserção no mercado de trabalho de Manacapuru dos trabalhadores oleiros oriundos desse município. Desprovidos de um nível de qualificação profissional que lhes permita obter um emprego na cidade, esses trabalhadores têm nas olarias uma das escassas formas de ganharem o sustento para si e para suas famílias. Daí a dependência que se estabelece entre esses indivíduos e o emprego oleiro. Em outras palavras, o medo que surge em face da possibilidade de perder o emprego na olaria é reflexo direto do medo de não conseguir emprego em Manacapuru, ficando, portanto, à margem do mercado de trabalho urbano.

Poderia se argumentar que, ainda que perdessem o emprego na olaria em que trabalham hoje, os trabalhadores poderiam conseguir emprego em outra olaria. Mas aqui é que está a questão principal, e que constitui o terceiro elemento revelado pelos dados da tabela, qual seja, a distância dessas outras olarias em relação à cidade de Manacapuru. Eis o ponto-chave: das 25 olarias de Iranduba, a olaria na qual realizamos a pesquisa é a mais próxima de Manacapuru (48 km). A outra olaria mais próxima está a uma distância de $63 \mathrm{~km}$ deste município, o que, em termos de preço das passagens de ônibus - que é, como vimos, uma das principais reclamações dos trabalhadores - significaria um custo alto comparado ao valor que se paga até a olaria em que eles trabalham hoje.

Novos Cadernos NAEA, v. 16, n. 1, Suplemento, p. 127-162, nov. 2013 
Como última questão, perguntamos aos trabalhadores se eles eram felizes no atual emprego. Conforme mostra a Tabela 17, mais de $80 \%$ dizem ser felizes. Para estes, a felicidade está relacionada ao fato de "[...] poderem estar trabalhando, ao invés de está por aí, desempregado, ou fazendo coisa errada” (Seu André, 45 anos, morador da Vila do Ariaú). Isso mostra, dessarte, que a felicidade desses trabalhadores está ligada a uma postura em relação à vida, ao valor que dão ao trabalho no sentido amplo, sem levar em conta as condições de precariedade ou controle do trabalho, mas sim a satisfação que têm em trabalhar, não importando o tipo específico de trabalho.

Do número restante, cerca de 15\% dizem ser infelizes, enquanto pouco mais de $2 \%$ não souberam responder. Do conjunto dos que se dizem ser felizes, cerca de $80 \%$ têm mais de 30 anos de idade. Já os que dizem ser infelizes, cerca de $90 \%$ têm idade menor que 30 anos, o que mostra que pretendem buscar um emprego melhor. Isso é revelado na opinião de um desses trabalhadores "infelizes": "[...] não sou feliz nesse trabalho não. Só trabalho aqui porque é o jeito. Se tivesse outro [emprego] deixaria esse e iria embora" (Marcelo, 25, morador de Manacapuru). Eis abaixo os dados da Tabela 17 em quantidade e porcentagem:

Tabela 17. Felicidade no emprego atual.

\begin{tabular}{l|c|c}
\hline \multicolumn{1}{c|}{ Felicidade } & Quantidade & Porcentagem (\%) \\
\hline Muito feliz & 1 & 2,63 \\
\hline Feliz & 30 & 78,95 \\
\hline Infeliz & 6 & 15,79 \\
\hline Não sabe & 1 & 2,63 \\
\hline Total & $\mathbf{3 8}$ & $\mathbf{1 0 0}$ \\
\hline
\end{tabular}

Fonte: Pesquisa de campo, 2012.

Diante de todo esse conjunto de questões que postulamos no decorrer desta seção, e que mostram um grau significativo de precariedade, de insatisfação e de controle do trabalho, fica "no ar" o questionamento acerca do modo que os trabalhadores reivindicam as melhorias no ambiente de trabalho, bem como da forma de organização dos mesmos e da participação deles em sindicatos da classe e, também, da participação do sindicato nas lutas pelos direitos da categoria. É o que faremos no próximo tópico.

\section{O SINDICATO E OS TRABALHADORES}

O sindicato que "representa" os trabalhadores da categoria oleira é o Sindicato dos Trabalhadores oleiros do Estado do Amazonas, com sede 
em Manaus e com mais de 600 filiados. Levando em conta o número total de trabalhadores oleiros do município de Iranduba (cerca de 1200), observa-se que apenas 50\% dos trabalhadores estão ligados à ação sindical.

Para o presidente do sindicato, a pequena adesão ao movimento está ligada à baixa escolaridade dos trabalhadores, que acabam por não entender qual o papel do sindicato nas fábricas e, assim, não se filiam. Além disso, segundo o presidente, vários trabalhadores são amigos dos donos, e a relação com o sindicato passa a ser mal-vista pelos proprietários.

[...] o fator escolaridade é um caso que gera muita desconfiança. É preciso muito diálogo paciência e carinho para lidar com eles. Tenho aprendido muito com esses meus companheiros. O trabalho em olaria é muito estafante, embora as empresas tenham melhorado a sua estrutura o ambiente de trabalho ainda é insalubre, muita poeira e calor, isso limita os trabalhadores até mesmo para tentarem se qualificar (presidente do sindicato).

Não obstante a baixa sindicalização, de acordo com o presidente do sindicato, este tem sido atuante, e estado presente constantemente nas olarias para ouvir os trabalhadores e promover discussões, tendo em vista a melhoria no ambiente produtivo. Nas palavras do próprio presidente: "Nossa atuação é permanente, visitamos as empresas, orientamos os trabalhadores e discutimos melhorias tanto no ambiente e condições de trabalho, como na questão salarial".

Em termos de conquistas da categoria, o presidente aponta que:

Depois que assumimos o Sindicato temos conseguido algumas conquistas. Para nós sindicalistas as conquistas serão sempre motivo para perseguirmos novas frentes de batalhas. No caso das Olarias é importante entender que estamos lidando com um tipo de empresa com capacidade muito reduzida de investimento, isso leva naturalmente a precarização da mão de obra. Passando pouco mais de cinco anos, podemos dizer que já houveram (sic) melhorias no setor, mas ainda é muito tímido no quesito ambiente de trabalho. É uma batalha que ainda vamos ter que insistir muito até resolverem (Idem).

Na empresa pesquisada o número de trabalhadores sindicalizados é menor do que a média apontada pelo presidente do sindicato, como podemos observar na Tabela 18:

Tabela 18. Porcentagem de sindicalização.

\begin{tabular}{l|c}
\hline Trabalhadores & Porcentagem (\%) \\
\hline Sindicalizados & 87 \\
\hline Não sindicalizados & 13 \\
\hline Total & $\mathbf{1 0 0}$ \\
\hline
\end{tabular}

Fonte: Pesquisa de campo, 2012.

Novos Cadernos NAEA, v. 16, n. 1, Suplemento, p. 127-162, nov. 2013 
Qual seria uma possível explicação para a baixa taxa de sindicalização na empresa? Cremos que podemos apontar, dentre outros fatores, a própria distância geográfica que existe entre os trabalhadores e a sede do sindicato. Era de se esperar que a sede estivesse localizada no município de Iranduba. Mas, como já dissemos, ela localiza-se no centro da cidade de Manaus, o que dificulta a ida dos trabalhadores até o local.

Nesse caso, o sindicato teria de ir ao encontro dos trabalhadores, convocando-os para os debates, e, dessarte, incentivando-os à participação enquanto membros da organização sindical. Entretanto, segundo os trabalhadores da empresa pesquisada, não é isso que ocorre. Pelo contrário, conforme informa Seu Fabrício, 44 anos:

Eu trabalho aqui há mais de sete anos, e nunca vi esse tal de sindicato aparecer. Eu sei que eles descontam um valor na carteira [de trabalho] que é para pagar o sindicato, mas não sei nem para que serve. Acho que eles [o sindicato] só fazem ficar com nosso dinheiro mesmo.

O que esse trabalhador aponta é significativo, e revela um contra-discurso aquilo que o próprio presidente do sindicato assevera: que tem efetuado visitas constantes às empresas. Durante um período de sete anos, o trabalhador citado nunca foi convocado para uma reunião sindical e nunca viu o presidente do sindicato na empresa, o que nos direciona a uma certa dimensão da fragilidade existente na relação entre sindicatos e trabalhadores.

Acresce a esse dado, o fato de os trabalhadores pagarem um valor ao sindicato e que lhes redunda em benefícios concretos. Na verdade, pagam o sindicato, mas não sabem qual o papel deste na organização dos trabalhadores. Aqueles que são sindicalizados relatam que, quando do contrato de trabalho com a empresa, esta pergunta se eles vão querer se filiar ao sindicato. No caso positivo, assinam um documento onde consta que serão descontados $\mathrm{R} \$ 11$ reais mensais referentes ao pagamento do sindicato.

Observa-se, com efeito, que o próprio ato de sindicalizar-se é intermediado pela empresa. É esta que leva o sindicato ao trabalhador, e não o inverso disso, qual seja, o sindicato, em seu papel histórico, indo ao trabalhador e sendo o instrumento de lutas pelas conquistas da classe operária.

Esse distanciamento do sindicato em relação aos trabalhadores da empresa leva ao desinteresse em sindicalizar-se, conforme relata Paulo, 33 anos:

[...] Não sei para quê vou pagar esse negócio de sindicato. Tem os meus amigos aí que pagam, mas eu não vejo eles [o sindicato] fazerem nada por eles [os trabalhadores]. Tu já viu esse sindicato aparecer aqui alguma vez para fazer alguma coisa pela gente [perguntando para um trabalhador que estava ao lado]? Vem nada! Só vejo o pessoal que paga dizer que vem descontado no pagamento um dinheiro, acho que é uns onze reais. Mas eu vou ficar pagando isso para quê? Para não ter nada em troca? [...]

Novos Cadernos NAEA, v. 16, n. 1, Suplemento, p. 127-162, nov. 2013 
Como análise, podemos dizer que não é que o trabalhador não tenha interesse no sindicato, pois muitos que são sindicalizados me perguntaram onde estava localizada a sede sindical, e pediram o telefone, dizendo que iriam ligar para solicitar melhorias. A questão central é o distanciamento que o próprio sindicato mantém em relação aos trabalhadores, não realizando visitas, não entregando panfletos, não fazendo uma campanha por melhorias salariais e das condições de trabalho.

Na lógica sindical aparece um discurso de atuação constante. Mas na fala dos trabalhadores esse discurso não passa de uma retórica. Eles não confirmam aquilo que o sindicato assevera. Há, portanto, um descompasso entre o discurso sindical e a realidade oleira.

Isso tem implicações práticas importantes, pois os trabalhadores ficam sem ter uma direção, já que essa é um dos objetivos da luta sindical, e, assim, não conseguem unir forças para estruturar uma ação coletiva que vise à qualidade do trabalho, à saúde do operário e a um nível salarial maior. Isso fica patente quando perguntamos a um trabalhador como eles fazem para reivindicar as demandas da categoria, uma vez que a atuação do sindicato não se faz presente na olaria:

A gente não faz nada. Não tem líder, não tem ninguém. $O$ pessoal até tentou reunir uma vez aí, mas não deu certo. Tem uns que podem dedurar [os trabalhadores] para o chefe, e aí vem confusão para cima da gente. Aí é melhor a gente ir trabalhando e ir levando a vida, né? [...] (ALBERTO, 30 anos).

$\mathrm{Na}$ Tabela 19 elencamos quais são as principais reivindicações dos trabalhadores as quais o sindicato, se estivesse atuante na olaria, poderia lançar mão como bandeira de luta. Em primeiro lugar, encontram-se as mudanças nas condições de trabalho, o que já vem se mostrando como uma das principais reclamações dos trabalhadores. Em segundo, está o aumento de salário, e, em terceiro, o transporte para Manacapuru e o lazer.

Tabela 19. Reivindicações dos trabalhadores.

\begin{tabular}{l|c|c}
\hline Reivindicações & Quantidade & Porcentagem (\%) \\
\hline Condições de Trabalho & 7 & 18,4 \\
\hline Deslocamento para Manacapuru & 2 & 5,2 \\
\hline Lazer & 2 & 5,2 \\
\hline Aumentar o salário & 4 & 10,5 \\
\hline Nada & 17 & 44,7 \\
\hline Outros & 6 & 15,7 \\
\hline Total & $\mathbf{3 8}$ & $\mathbf{1 0 0}$ \\
\hline
\end{tabular}

Fonte: Pesquisa de campo, 2012.

Novos Cadernos NAEA, v. 16, n. 1, Suplemento, p. 127-162, nov. 2013 
Impressiona-nos a porcentagem de trabalhadores que dizem não ter nada para reivindicar. Isso não mostra, de maneira alguma, que o trabalho não necessite de melhorias, pois, como vimos, os próprios trabalhadores têm apontado para diversas insatisfações em relação ao ambiente produtivo. Aqui a questão central é o elemento da reivindicação, da busca por ação que exige uma organização coletiva, em suma, de uma atitude de resistência de classe, face às artimanhas do capital (MARX, 1985).

Contudo, desacreditados de que suas atitudes possam mudar algo, os trabalhadores preferem "ir trabalhando e ir levando a vida", como vimos na fala do Alberto. Desprovidos desse instrumento de luta - o sindicato - os trabalhadores oleiros são entregues aos próprios ditames do capital, corporificados nas estratégias empresariais, que visam, de certa forma, preencher o vazio deixado, sobretudo pela não atuação sindical. Faz parte destas estratégias uma série de reordenamentos industriais, tendo em vista racionalizar a produção, na perspectiva de que os trabalhadores incorporem o "espírito da empresa". Vejamos quais foram esses reordenamentos.

\section{RACIONALIZAÇÃO DO TRABALHO E REORDENAMENTO PRODUTIVO NA OLARIA}

Já nos dizia Weber (2004) que o processo de racionalização das empresas capitalistas modernas ocorre a partir de um controle contábil dos custos, das formas racionais de organização do trabalho e da mecanização. Isso significa, concretamente, que a modernização do capital envolve práticas produtivas que visam agir racionalmente com respeito a fins, buscando meios que possibilitem a objetivação da máxima capitalista: a busca do lucro.

Na empresa pesquisada, o processo de racionalização da estrutura produtiva se deu exatamente no caminho apontado por Weber, qual seja, a introdução de elementos produtivos que visaram estabelecer metas de produtividade, busca por qualidade e controle do processo produtivo. Uma dessas formas de racionalização do trabalho diz respeito à adoção de inovações organizacionais de origem japonesa, que são chamadas de $\mathrm{CCQ}^{15}$. A estratégia desses programas consiste em identificar os problemas na fonte antes que eles comprometam o desempenho de um setor da empresa, ou da empresa como um todo.

$\mathrm{Na}$ pesquisa realizada, observamos que a gerência da mesma apresentou o projeto de melhoria contínua para os trabalhadores do setor de administração da olaria e, depois, para todos os "colaboradores", tentando, nesse sentido, detectar os principais problemas que afetavam o desempenho industrial da mesma.

15 Círculo de Controle de Qualidade.

Novos Cadernos NAEA, v. 16, n. 1, Suplemento, p. 127-162, nov. 2013 
Assim, buscou-se conscientizar os trabalhadores sobre a importância do trabalho em equipe $e^{16}$ no processo de desenvolvimento das inovações, além de disponibilizar o projeto impresso para cada um deles, na perspectiva de despertá-los para a busca da melhoria sistemática enquanto um objetivo a ser alcançado.

Os trabalhadores, em conjunto com a liderança, reuniam de 15 em 15 dias. Era nessas reuniões efetuadas dentro do período de trabalho dos funcionários, que os líderes e colaboradores avaliavam a execução de cada etapa do projeto e traçavam as novas metas a serem alcançadas pela empresa, mapeando todas as etapas do processo de fabricação.

Nosso interesse em mostrar parte dessa pesquisa está em trazer a lume a perspectiva de que esse processo de racionalização da produção vincula-se ao objetivo do capital em estabelecer constrangimentos sobre o trabalho, tentando, dessarte, deixá-lo subordinado, sob seus tentáculos. Assim, promove-se uma série de mudanças na forma de organização da produção a fim de estabelecer parâmetros de racionalidade produtiva e de controle do trabalho.

Na olaria, a primeira dessas alterações concerne à própria contratação dos trabalhadores que preenchem o quadro de funcionários. A partir da adoção das inovações organizacionais e da emergência da ideia de que o trabalho em equipe é o cerne do ganho de produtividade, a cerâmica passou a estabelecer uma política de contratação baseada no critério do grau de escolaridade. Se o processo de trabalho tradicionalmente executado nas olarias não exigia domínio de tecnologias ou o uso de ferramentas tecnicamente avançadas, no momento em que se implementaram a introdução de inovações, a empresa buscou uma mão de obra operacional de escolaridade e formação mais elevada (MACIEL; VALLE, 2010).

Esse processo de contratação tem em vista uma espécie de domesticação do trabalho, uma vez que na filosofia empresarial da cerâmica pesquisada os trabalhadores que possuem capital cultural superior estão aptos a se envolverem com maior afinco às tarefas determinadas pelo Círculo de Controle de Qualidade. Nesse contexto, portanto, a escolaridade assume um papel interessante na análise do setor oleiro, na medida em que é ela quem estrutura a base de contratação das empresas nessa transição industrial que emerge em Iranduba. A mão de obra qualificada torna-se um elemento-chave para se pensar na superação da crise de produção que as olarias vinham enfrentando desde a década de 1990, sendo que a construção de escolas de treinamento dentro da própria planta industrial configurar-se-á como uma estratégia decisiva na gestão da produção.

Além disso, a empresa busca uma mão de obra qualificada em face da tentativa de se atingir a estabilização de uma força de trabalho, diante de um

\footnotetext{
16 Alves (2010) aponta que essa ideia do "trabalho em equipe", na verdade, faz parte de um processo de "captura" da subjetividade do trabalhador, pois busca transformar valores reconhecidamente humanos, como a solidariedade, em fonte de lucro para o empresário capitalista.
}

Novos Cadernos NAEA, v. 16, n. 1, Suplemento, p. 127-162, nov. 2013 
processo anterior de contratação, com altos índices de absenteísmo. Posicionando estrategicamente diante desse fato, a empresa estabeleceu que se o trabalhador não faltar nenhum dia da semana, ele receberá uma bonificação em dinheiro no final de semana. Assim, elas criam parâmetros para se alcançar maiores índices de produção, buscando aquilo que Boltanski e Chiapello (2009) designaram como flexibilidade funcional, quer dizer, a ação contínua sobre o trabalhador, envolvendo a cultura do "comprometimento" com a empresa, sendo o absenteísmo considerado um mal a ser erradicado.

A segunda perspectiva de controle do trabalho é concernente a introdução dos Círculos de Controle de Qualidade na empresa. Fazer reuniões dentro do período de trabalho fez parte de uma estratégia para mostrar que as inovações organizacionais passaram a ter centralidade na empresa. Assim sendo, a introdução dos CCQs buscou aprofundar a extração do trabalho, capturando a força de trabalho não somente no plano técnico, mas na própria subjetividade do trabalhador. Pretende-se, dessa forma, "envolver" o operário com a política organizacional da empresa, seja oferecendo cursos sobre a importância da qualidade, seja introduzindo a bonificação como um modo de mostrar para o trabalhador que ele é "peça fundamental" (Figuras 5 e 6).

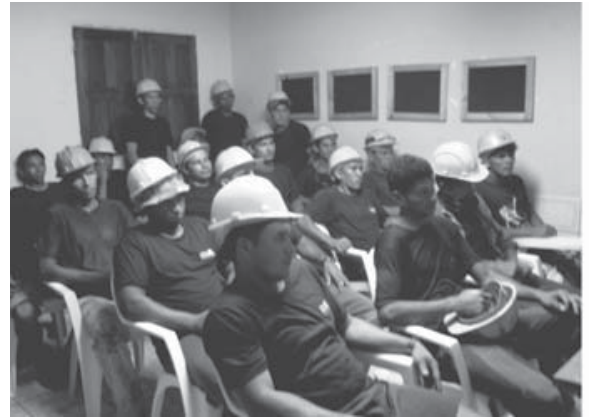

Figura 5. Reunião do Círculo de Controle de Qualidade. Foto do autor, 2010.

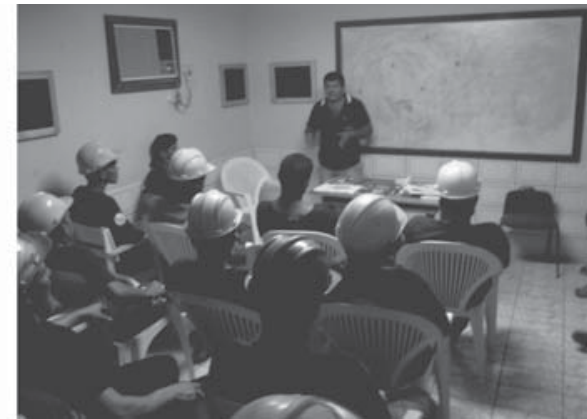

Figura 6. Os "colaboradores" recebendo treinamento da gerência da olaria. Foto do autor, 2010.

Nessa perspectiva, o discurso da cerâmica passa a estar voltado para a ideia de que os ganhos da empresa giram em torno do trabalho feito em equipe, no qual todos precisam de todos, formando um corpo produtivo bem ajustado. Destarte, aflora-se a "pedra de toque" da ação empresarial moderna (OLIVEIRA, 2007), ou seja, a filosofia de que o que mobiliza a empresa na adoção dessas inovações é a valorização do ser humano, introduzindo, em face disso, o espírito de cooperação entre trabalhador e empresa.

Deste modo, a responsabilidade da fabricação de tijolos nessa nova forma de gestão é colocada sobre o "colaborador". Fluxogramas (Figura 7) e croquis (Figura 8) indicando como se deve proceder em cada máquina ou que não fazer em determinado processo são espalhados pela fábrica, como uma 
tentativa de controle invisível sobre as etapas da produção. Podemos dizer que nessa organização da produção de tijolos em Iranduba, o papel de supervisionar a produção ou de inspecionar as etapas do processo de fabricação sai do plano tradicional, para uma dimensão do trabalho flexível, em que o inspetor não existe, mas está "bem ali", em cada canto do chão da fábrica, criando, assim, uma mentalidade favorável à concentração no trabalho, e estabelecendo o não desperdício com distrações e fantasias.

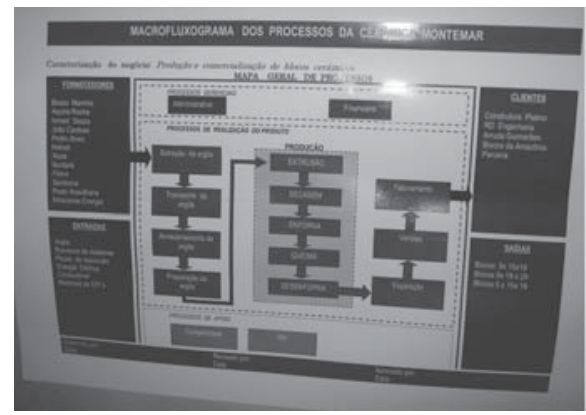

Figura 7. Um dos fluxogramas espalhados no "chão" da fábrica. Foto do autor, 2010.

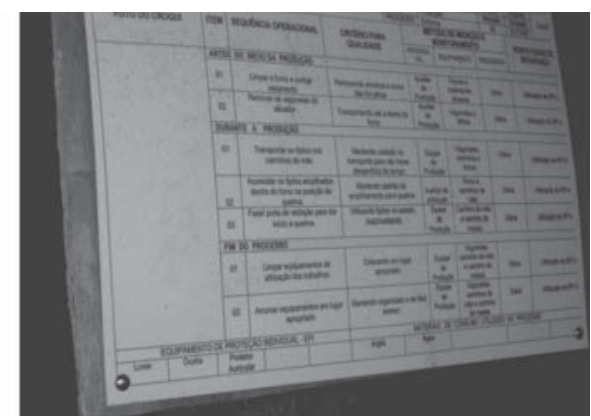

Figura 8. Croqui indicando como se deve proceder nas diversas etapas da produção. Foto do autor, 2010.

A terceira configuração de controle do trabalho diz respeito ao papel que a busca por ISOs ${ }^{17}$ adquire nesse momento de transição produtiva. Trata-se de uma exigência global, que visa unificar e padronizar comportamentos produtivos. Quando uma empresa persegue a certificação dada pelo ISO, ela precisa cumprir algumas cláusulas estabelecidas em parâmetros internacionais de normas fabris (MACIEL e VALLE, 2010). Uma dessas cláusulas se refere ao processo em que as auditorias exigem que os trabalhadores demonstrem conhecimento sobre os procedimentos de diversas etapas da produção de determinado bem.

Dessarte, a cerâmica na qual a pesquisa foi realizada tem como meta obter a certificação ISO 9000 e 14000 até o ano de 2013, sendo crucial a fixação de padrões de produção que possam garantir a aprovação na avaliação realizada por partes dos auditores que fazem visitas periódicas à olaria.

Logo, cada procedimento necessário para a integração entre qualidade e produtividade precisa estar articulado no processo de produção, constituindo-se, assim, numa forma de criar mecanismo de controle do trabalho, fixando metas a serem alcançadas a cada mês, avaliando os resultados da produção nas reuniões quinzenais, em face de uma visão sistemática e racional sobre os ganhos e perdas na produção.

17 International Organization for Standardization. Os ISOs 9000 e 14000 se referem a certificações dadas às empresas que buscam cumprir normas de gestão da qualidade e legislação ambiental, respectivamente.

Novos Cadernos NAEA, v. 16, n. 1, Suplemento, p. 127-162, nov. 2013 


\section{CONSIDERAÇÕES FINAIS}

Baseado nos dados evidenciados no decorrer desse trabalho, pode-se dizer que na relação entre empresa, trabalhadores e sindicato, a primeira tem logrado larga vantagem sobre estes últimos. Isso significa dizer que, por um lado, há a racionalização da produção, com a introdução de Círculos de Controle de Qualidade, e metas produtivas de longo prazo, como a obtenção da ISO 9000 e 14000. Mas, por outro lado, há a intensificação da precariedade das condições de trabalho, como também da relação que se estabelece entre a empresa e os trabalhadores, onde a pauta discursiva da fábrica passa a ser, concretamente, os ditames do capital.

Por exemplo: nas reuniões dos Círculos de Controle de Qualidade realizadas quinzenalmente não se discutiam temáticas que envolvessem diretamente o real interesse dos trabalhadores do setor oleiro, como jornada de trabalho, salários e condições de trabalho, os quais, como vimos, são precários.

Nesses meetings eram tratados os problemas da empresa que dissessem respeito tão somente à busca pela qualidade e produtividade. O que ficou patente nas reuniões foram as apresentações de resultados produtivos positivos alcançados por diversas empresas, como a Toyota, ao adotarem determinadas inovações organizacionais e de processo, tornando ausente, assim, o questionamento dos trabalhadores oleiros sobre o papel que essas estratégias organizacionais tiveram na desarticulação, por exemplo, dos sindicatos das fábricas do Polo Industrial de Manaus (VALLE, 2007).

Dentro do conflito capital-trabalho, o controle da produção assume, portanto, contornos pragmáticos, ou seja, a tentativa de organizar os trabalhadores em torno da empresa, não em torno de si mesmos. O número, por exemplo, de pessoas que podiam participar das reuniões do Círculo de Controle de Qualidade era definido pela gerência, ou seja, uma decisão vertical que visava horizontalizar resoluções tomadas pelo próprio setor administrativo, embora o discurso fosse de que "não existe hierarquia na empresa".

Ela, de fato, fica invisível quando se olha pela primeira vez para a organização produtiva oleira, contudo, torna-se patente quando analisamos os contornos das estratégias empresariais adotadas, uma vez as temáticas discutidas nas reuniões, a formulação de metas a serem alcançadas e os mecanismos de integração do trabalhador adotado pela olaria são direcionadas para a busca de produtividade e qualidade, em detrimento das necessidades dos trabalhadores.

A questão que se coloca, nesse sentido, é encontrar meios de reverter tal situação. O sindicato, como aponta Antunes (2005) e também Cipolla (2005), seria o caminho mais direto para lutar pelos direitos da classe trabalhadora, mas, na olaria, tem se mostrado letárgico. Em face disso, cremos que a Ciência, 
e, no nosso caso, a Sociologia enquanto elemento de compreensão do mundo, mas também como forma de transformação da realidade, pode ajudar a alterar os contornos desse cenário produtivo, ou seja, ampliando o leque de pesquisas direcionadas à temática do trabalho local, para que, dessa forma, seja revelada à sociedade a configuração do mundo do trabalho desse setor industrial, seus rostos, suas falas e suas reivindicações.

Em outras palavras, tendo um comprometimento social do fazer sociológico, uma vez que nos dados da pesquisa há vozes de sujeitos que anseiam por melhores condições de vida, trabalham em precárias condições humanas e precisam, portanto, ser ouvidos pela sociedade. Sem isso, corre-se o risco da Sociologia se converter apenas em técnica e estética, em suma, em contemplação intelectual do mundo. Nesse ponto recorremos a Bourdieu (2000, p. 92), o qual, refletindo sobre o papel da Sociologia, incita-nos à reflexão, mas também à transformação social:

A sociologia talvez não merecesse uma hora de esforço se tivesse por finalidade apenas descobrir os cordões que movem os indivíduos que ela observa, se esquecesse que lida com os homens, mesmo quando estes, à maneira das marionetes, jogam um jogo cujas regras ignoram, em suma, se ela não se desse à tarefa de restituir a esses homens o sentido de suas ações.

\section{REFERÊNCIAS}

ABREU, S. A empresa oleiro-cerâmica do município de Iranduba. Monografia. Manaus: UFAM/Faculdade de Estudos Sociais, 2004.

ACERAM-Associação dos Ceramistas do Estado do Amazonas. Relatório da APL de Base Mineral: Central de Resíduos. Manaus: ACERAM, 2012.

ALVES, G. A. P. Trabalho, capitalismo global e a "captura" da subjetividade: uma perspectiva crítica. In: SANT'ANA, R. S. et al. (Org.). O avesso do trabalho II: trabalho, precarização e saúde do trabalhador. 1. ed. São Paulo: Expressão Popular, 2010. 464 p.

. Trabalho e Mundialização do capital: a nova degradação do trabalho na era da globalização. Londrina: Praxis, 1999.

ANICER-Associação Nacional da Indústria Cerâmica. Curso: a implantação de controles para melhoria da qualidade de produto cerâmico. Rio de Janeiro: ANICER, 2012.

ANTUNES, R. Os sentidos do trabalho: ensaio sobre a afirmação e a negação do trabalho. 2.ed. 10. reimpr. rev. ampl. São Paulo: Boitempo, 2009. 
BOURDIEU, P. Contrafogos 2: por um movimento social europeu. Rio de Janeiro: Zahar, 2001. 115 p.

BOLTANSKI, L.; CHIAPELLO, È. O novo espírito do capitalismo. São Paulo: Martins Fontes, 2009.

CASTRO, E. (Org.). Cidades na Floresta. São Paulo: Annablume, 2008.

CERÂMICA CA1. Gestão de Qualidade. Relatório. [s.l.]: [s.n.], 2011.

CHAVES, S. W. Q. Estudo de Mercado da Produção de tijolos no Município de Iranduba. Monografia. Manaus: UFAM/Faculdade de Estudos Sociais, 1999, 2001.

CIPOLLA, F. P. Trabalho em equipe como forma de subsunção real. Est. Econ., São Paulo, v. 35, n. 1, p. 203-232, 2005.

LIMA, M. C. de. Amazônia Ocidental e Geografia: Região Metropolitana de Manaus e BR 319 - Território e Meio Ambiente. Revista GEONORTE, Manaus, v. 1, n. 1, p. 47-70, 2010.

MACIEL, C. F.; VALLE, M. I. de M. As inovações tecnológicas no Pólo oleiro-cerâmico de Iranduba-Am: um estudo de caso. Relatório Final. Manaus: UFAM/Programa Institucional de Bolsa de Iniciação Científica, 2010.

MARX, K. O capital: crítica da economia. 2. ed. Tradução de Regis Barbosa e Flávio R. Kothe. São Paulo: Nova Cultural, 1985.

; ENGELS, F. A ideologia alemã. 3. ed. Tradução de Luis Claudio de Castro e Costa. São Paulo: Martins Fontes, 2007.

NEAPL-Núcleo Estadual de Arranjos Produtivos Locais. Plano de Desenvolvimento Preliminar: APL de Base Mineral cerâmico-oleiro. Manaus: GTPAPL, 2009.

OLIVEIRA, S. S. B. de. A "periferia" do capital: na cadeia produtiva de eletroeletrônicos. Manaus: EDUFAME, 2007.

SEBRAE-Serviço Brasileiro de Apoio às Micro e Pequenas Empresas. Manual para a Indústria de Cerâmica Vermelha; redução dos desperdícios e maior eficiência no setor: Fascículo 1. 2. ed. atual e aum. Rio de Janeiro: SEBRAE/RJ, 2011.

TRINDADE, P. Análise do desempenho da economia oleiro-cerâmica do município de Iranduba. Monografia. Manaus: UFAM/Faculdade de Estudos Sociais, 1999. 
VALLE, I. Globalização e reestruturação produtiva: um estudo sobre a produção offshore em Manaus. Manaus: EDUFAM, 2007.

WEBER, M. Economia e Sociedade: fundamentos da sociologia Compreensiva. Ttradução de Regis Barbosa e Karen Elsabe Barbosa. Brasíli, DF: EDUNB, 2004. 